\title{
TNFRSF1A wt Allele
}

National Cancer Institute

\section{Source}

National Cancer Institute. TNFRSF1A wt Allele. NCI Thesaurus. Code C51380.

Human TNFRSF1A wild-type allele is located in the vicinity of 12 p13.2 and is approximately $13 \mathrm{~kb}$ in length. This allele, which encodes tumor necrosis factor receptor superfamily member $1 \mathrm{~A}$ protein, is involved in the mediation of both apoptosis and inflammation. Mutations in the gene are associated with autosomal dominant familial periodic fever. 